Рад примљен: 14. 7. 2017.

Рад прихваћен: 15. 12. 2017.

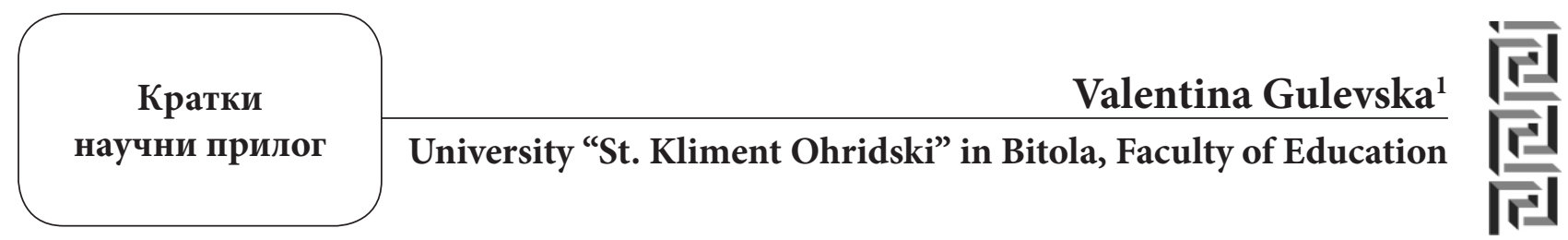

\title{
Teachers' Perceptions of Parental Involvement in Primary Education
}

\begin{abstract}
Summary: In this paper, we are taking an in-depth look at communicating with families of students in primary schools and there is a current research as the basis. Focusing on the partnership between teachers and parents, this research analyses different elements: communicating with families about the student's success, communicating with families in meetings, and addressing difficult topics with families. Additionally, a broad-based analysis is made regarding working with families of general education students, students with disabilities, students from low socio-economic status, and students with unique gifts and talents. Sometimes teachers working with families may become frustrated by the parents' apparent inability to dedicate their attention fully on matters regarding their children. At that point, there is a tendency of determination of teachers' perceptions of both the benefits of creating productive partnerships with parents, on one side and the barriers that must be overcome, on the other side.
\end{abstract}

Keywords: teachers, parents, partnership, children needs, education.

\section{Introduction}

Education is too important to be left solely to educators.

Francis Keppel

Most children have two main educators in their lives: their parents and their teachers. Parental involvement in children's education from an ear- ly age has a significant effect on educational achievement. There is no universal agreement on what parental involvement is, but it can take many forms. This issue can be divided into two broad patterns: parents' involvement in the life of the school and parents' involvement in support of the child at home. This article is focused on the first of these, as there is consistent evidence of the educational benefits of involving parents in the life of the school.

1 valentina.gulevska@uklo.edu.mk

Copyright $\odot 2017$ by the authors, licensee Teacher Education Faculty University of Belgrade, SERBIA.

This is an open access article distributed under the terms of the Creative Commons Attribution License (CC BY 4.0) (https://creativecommons.org/licenses/by/4.0/), which permits unrestricted use, distribution, and reproduction in any medium, provided the original paper is accurately cited. 
It has long been recognized by education experts that the quality of home-school relationships is associated with many benefits for children, families and schools: enhancing children learning opportunities, accessing to the knowledge that parents have of their children, making better decisions, building support for schools and so on. From this point, parental involvement in schools is one of the most important factors in the educational success. However, we do not know much about how the teachers can make the school more welcoming for all parents and how the parental involvement can palliate the restrictions of poverty for disadvantaged students. Moreover, not all parents have the same capacities or opportunities to act on the educational expectations they have for their children. In that line, schools self-interest is to have a parent engagement strategy that does not settle at having a few parents on a school site council. In addition, many savants think that coming to informative meetings or to school events is not an effective parent engagement strategy (Ferlazzo \& Hammond, 2009).

A crucial key to parental involvement is the forcefulness of the relationships between parents and the school. There are, also, many advantages for the teachers coming from the strong parent-teacher relationship in addition to those enjoyed by the students: "When teachers have positive relationships with students' parents, understanding of and support for classroom curriculum and activities rises. Collaboration often leads to improved ideas, enriched resources (e.g. volunteers, donations), expanded trust, and increased teacher willingness to try new things. All of these, in turn, lead to improved teacher confidence, job satisfaction and self-esteem. In general, the teachers who have strong positive relationships with parents appear to have more energy and less stress. They brought home into the discussion and made the school an extension of the child's life with his or her family" (Olender et al., 2010, p. 4).Perhaps most important to be mentioned is that parents, with their social capital and life experience, on the one hand, and provided by the teachers' in- structions, on the other hand, may become confident helpers in their children's education.

\section{Methods}

This research, the results of which are outlined in the subsequent pages, was conducted in order to gain insights into how teachers comprehend the impact of parental involvement in the life of the school. Additionally, a broad-based analysis is made regarding working with families of general education students, students with disabilities, students from low socio-economic status, and students with unique gifts and talents. The methodology of the research rests upon the preparation and design of a standard questionnaire adapted to four broad categories in which, in our opinion, parents should be involved in the life of the school: student achievement, informative parents' meeting through the school year, families as partners in school decisionmaking, and parents' participation in conflict resolution. In addition, some of the teachers were interviewed regarding this issue.

The representative sample comprises 20 teachers from elementary schools in Bitola region. Fifteen teachers out of a total number work in the primary schools in urban area, 3 teachers work in the primary schools of rural area, and two teachers work in the institution for special education. Two are male, and eighteen are female interviewees. As for the ethnicity of the interviewees, 17 are Macedonians, one is Albanian, 1 is a Turk, and 1 is a Vlach. Questionnaires were handed out to all teachers selected to participate in the survey, providing enough time for their completion. Once completed, the questionnaires were collected in a way that ensured anonymity. Data collection was worked on from April $15^{\text {th }}, 2017$, through May $10^{\text {th }}, 2017$. Respondents were given the task to evaluate the frequency of parental involvement in the life of the school by checking one of the offered answers: "sometimes", "often" and "very often". 


\section{Results}

At first, the survey data show that primary school teachers have a positive attitude towards parental involvement in school but they find that in fact parental involvement in Macedonian schooling is poor and sporadic. Most teachers ascribe poor parent-school relationship to factors such as parental unwillingness to respond to school created partnership plans and to the parents' educational and social background.

Particularly, the research shows that attending informative meetings is the leading form of parent participation in the schools. On the contrary, parents' participation in the school decision making is structured on the very low level. Regarding conflict resolution, it seems that parents are very abeyant. When children "develop a reputation for exhibiting challenging behaviour their parents can be reluctant to go into schools for fear of getting more bad news" (Hornby, 2011, p. 18). In fact, there is usually a negative correlation between parental involvement and children's demeanour problems, such that the more turbulent the behaviour, the less parents are disposed to be involved in the school.(See Table 1).

Regarding parental help in the school according to the children needs, not surprisingly, the research shows that participation was greater for parents who have children with disabilities than for those with gifted and talented children. Teachers perceived that when children are striving with their schoolwork due to learning difficulties or disabilities, the parents are generally more bent to be active in parental involvement activities. Because the involvement of parents is necessary for the process of implementation individual education programs, this eases the involvement of many parents of children with learning difficulties or disabilities.

For children who are good students at school it is ordinarily a joy for parents to attend parentteacher meetings. However, obstacles to effective parental involvement can be evident when the schools are not responsive to the extracurricular demands

Table 1: Parental involvement in the life of the school

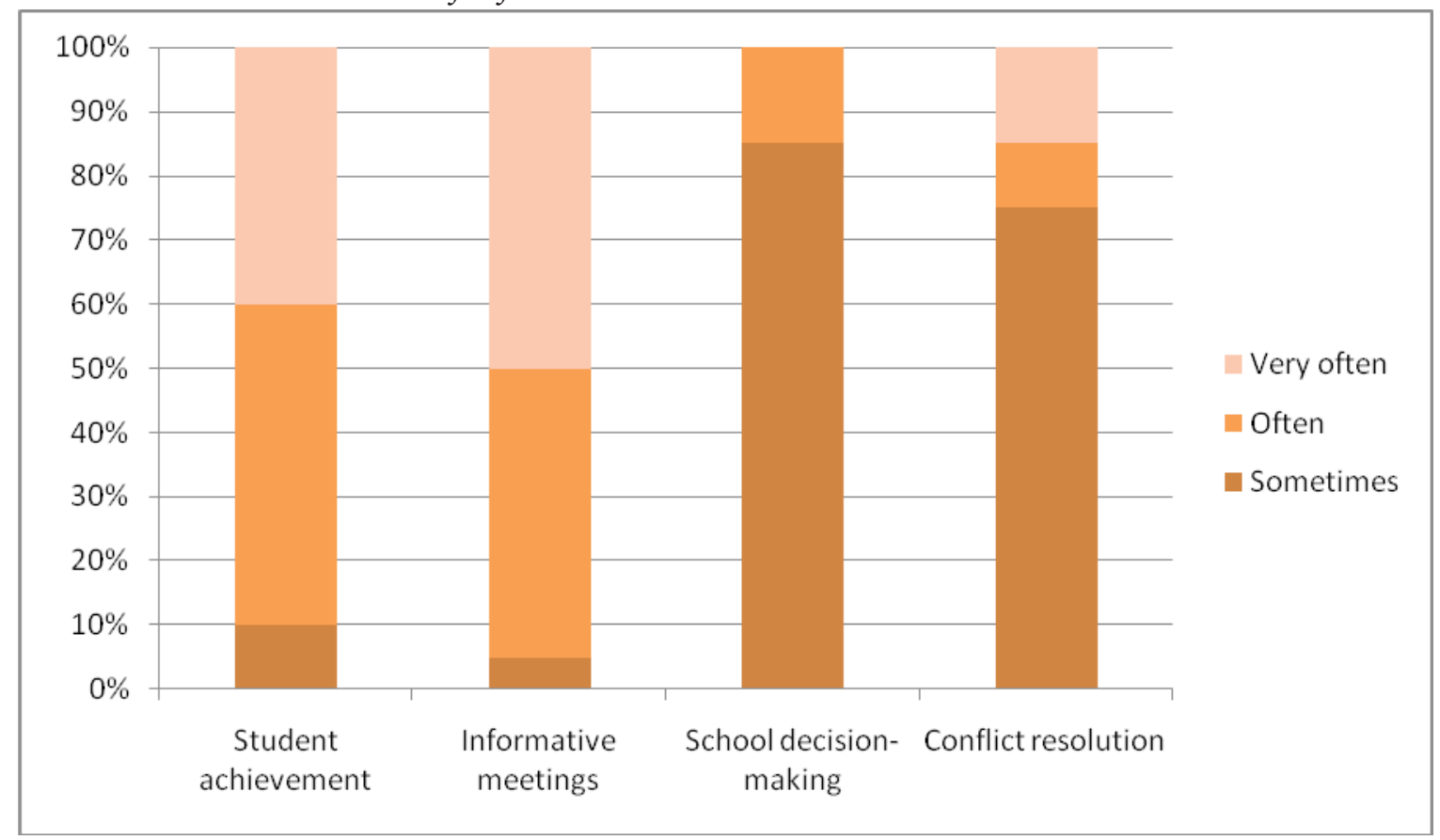


on the gifted children, because developing their talents requires a lot of time and effort practicing, which often needs taking time off school.

Background factors have also been taken into account (i.e. family socio-economic status). The research has found that there is no significant statistical difference between category "general education students" and "students with low socio-economic status". The teachers' opinions are that parents with high aspirations are more involved in their children's education and that high parental and pupil aspirations may lessen the effects of low socio-economic background. (See Table 2).

\section{Discussion}

Generally, the research shows that teachers' perceptions regarding parental involvement in primary education are focusing on the assertion that successful parent involvement in the children edu- cation improves not only student behaviour and attendance in the school, but also positively affects the student achievement. According to the interviewed teachers, parents should always be the ones who encourage or support their children regarding achievement of academic success. In this context, policy makers also argue that during the childhood, when critical decisions are to be made, extremely is important the parents being at schools for their children (Brown, 2013).

On the other hand, the analysis of the obtained results shows that more interventions are needed into developing effective parent engagement strategy because even the most involved and informed parents can feel overtaken and bewildered when making authoritative decisions about their child's education. In order to facilitate that involvement, the principals and the teachers, should learn. First, they should learn as much information as they can about the families served by their schools. In addition, the experts suggest that "conducting a school

Table 2: Parental help in the school according to the children needs

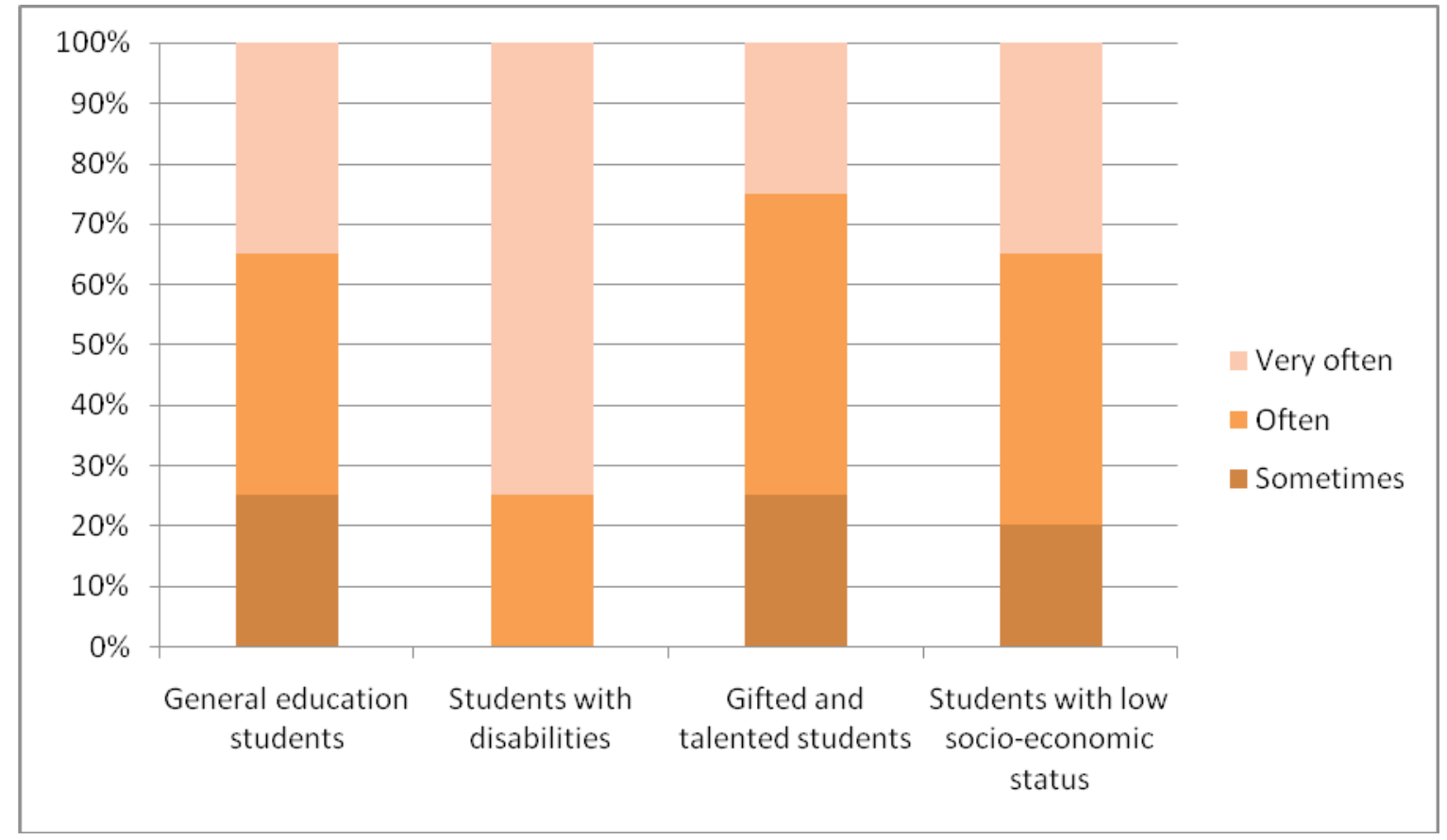


reality check provides valuable information to assist with the crucial task of reaching out to parents and is well worth the time and effort required" (Edwards, 2016, p. 17).

Additionally, it seems that home visits, as a powerful tool in the building partnerships between teacher and parents, are not utilized enough by the Macedonian schools. Because of that, the teacher training faculties should enrich the teacher-training syllabus, textbooks and teaching tools with educational content that will provide the opportunity for the future teachers to gain competencies for face-to face communication with parents in the comfort of the student's home. At the same time, it is particularly important to encourage all teachers to receive training on "how to introduce themselves to parents ... and negotiate an exchange of information" ( $\mathrm{Hi}$ att- Michael, 2013, p. 41). During the home visit, the teachers can suggest ways of parental involvement in the school that families may accept in order to foster confidence and relationship building.

Finally, we can conclude that, according to research findings, successful home-school collaboration may be more dynamic and cordial, and good example of shared decision-making. Therefore, our recommendations include the following parameters:

- Make plans for how the school can communicate with families and involve them in a variety of ways.

- Make parents equal partners with educators by allowing them a voice in school decisions.

- Encourage parents with gifted children to be more active in the school life.

- Count disadvantaged parents (with social or economic limitations) as part of the educational team

- Strengthen parent-teacher relationships through home visits.

It is may be correct to claim that parenting is solely the parents' responsibility and the teacher should stay completely out of it. However, we cannot avoid the fact that "the teacher is the parents' number-one resource" (Mandel, 2008, p. 22). Parents must start to encourage way of learning for their children in the first years of their schooling because it will help the students' success. If they wait too late, disappointment is expected.

\section{References:}

- Brown, A. A. (2013). Parent Engagement Effects - Student Drop Out, Bloomington: AuthorHouse LLC.

- Edwards, P. A. (2016).New Ways to Engage Parents: Strategies and Tools for Teachers and Leaders, K-12, New York: Teachers College Press, Columbia University.

- Ferlazzo, L., Hammond, L. (2009). Building Parent Engagement in Schools, Santa Barbara: ABC-CLIO.

- Hiatt-Michael, D. B. (2010). "Communication Practices that Bridge Home with School" in D. B. HiattMichael (Ed.), Promising Practices to Support Family Involvement in Schools, Charlotte: Information Age Publishing.

- Hornby, G. (2011), Parental Involvement in Childhood Education: Building Effective School-Family Partnerships, New York: Springer.

- Mandel, S. (2008). The Parent-Teacher Partnership: How to Work Together for Student Achievement, Chicago: Zephyr Press.

- Olender, R. A., Elias, J., Mastroleo, R. D. (2010).The School-Home Connection: Forging Positive Relationships With Parents, Thousand Oaks: Corwin. 


\section{Валентина Гулевска}

Педагошки факултет, Универзитет „Свети Климент Охридски“ у Битољу,

Република Македонија

\section{МИШЉЕЊЕ НАСТАВНИКА О УЧЕШТУ РОДИТЕЉА У ОСНОВНОМ ОБРАЗОВАЊУ}

Резиме: Учешће родительа у основном образовану иресстиавъа юихово акииивно, неиррекияно аніажоване у образовном ироцесу юихове деце. Према мишьеньу ситручғака, ро-

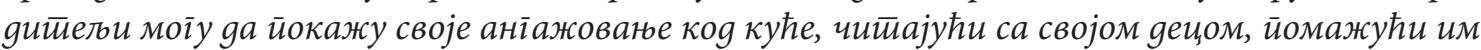
око gомаћих заgайака и разїовором у вези са школским gоїађајима или у школи иррисустивованем на састианиима и волонтииранем у учионицама. Понекаg настиавници који раяе са

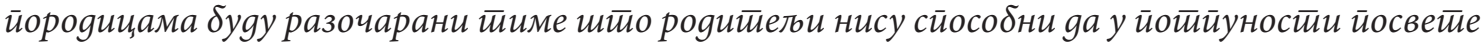

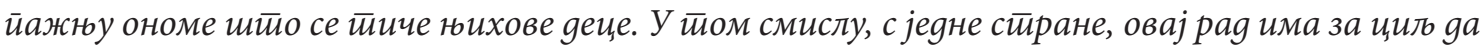

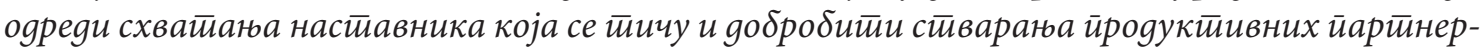

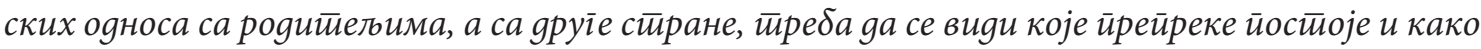
моїу gа се уклоне. Ово иситраживане је усреgсређено на комуникацију школе са йородицама

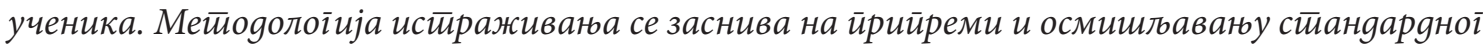

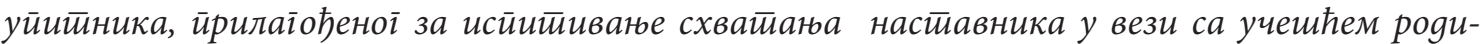

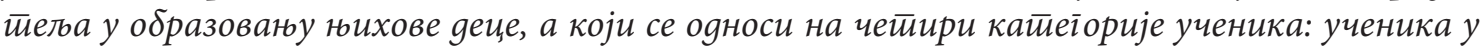

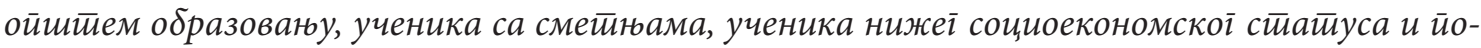
себно gаровитихх ученика. Такође, у овом истираживағу се анализирају различитии елементии ілавне иеме: комуникација са йородицама која је у вези са усиеехом ученика, комуникаиија са йородицама на сасиинцима и разіовор са йородицама о ииешким ииемама. Реирезенйа-

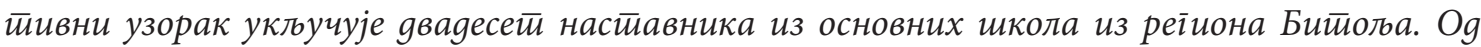

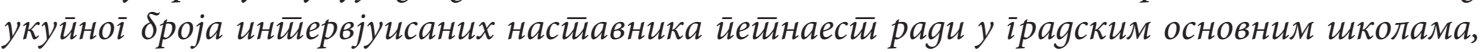

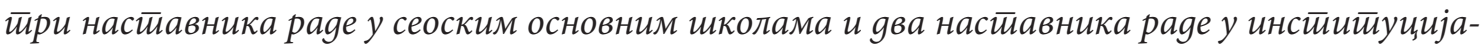
ма за сиечијално образоване. Прикуйлане йоgайака је обављено између 15. аиррила 2017. и

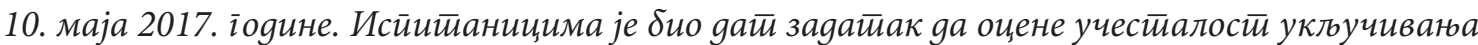

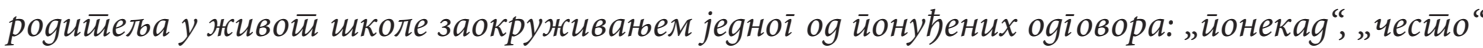
и „веома честио“. Истираживаюе је йоказало да учестивованем на информаииивним састиан-

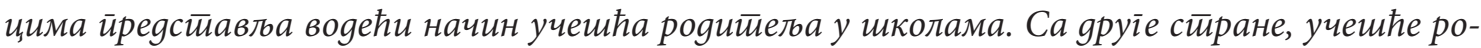

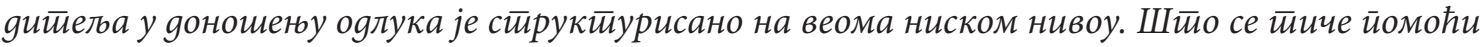

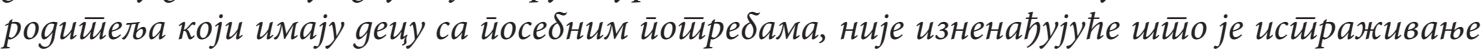
иоказало gа је юихово учешће било веће оg оних који имају gаровитиу gеиу. Такође су узе-

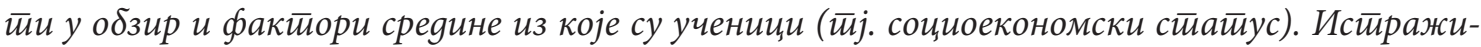

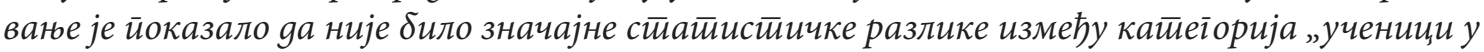

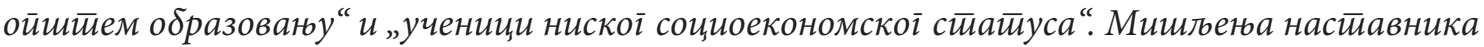

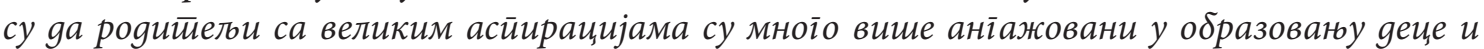
gа велике асйирације родитетьа и ученика моїу gа умаюе ефекие скромне соичоекономске

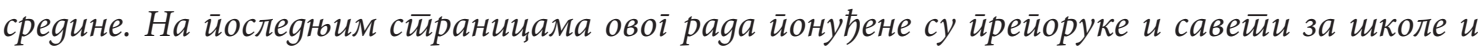

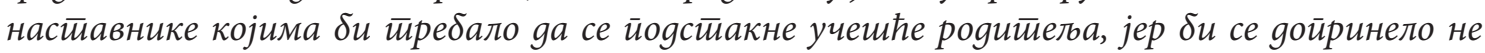

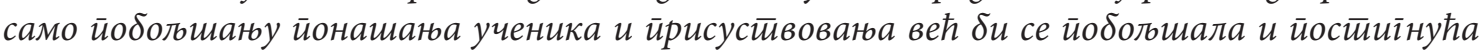


ученика. Према резулитайима исирраживаға, усиетна сараяна између куће и школе може gа уклучи и слеgеће: ирравтене итланова како школа може gа комуницира са йородицама и како може gа их укључи у образоване на различите начине, како яа родииееље учини равнойравним йарйнерима настиавницима, омоі̄ућавајући им gа gају ілас йриликом gоношења

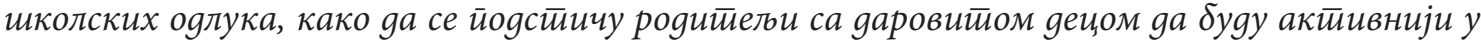

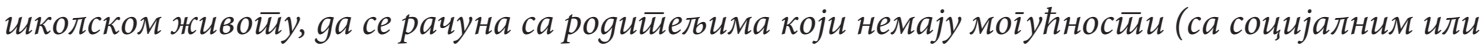
економским оіраниченима) као са делом образовноі йима, gа се јачају односи између роди-

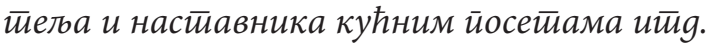

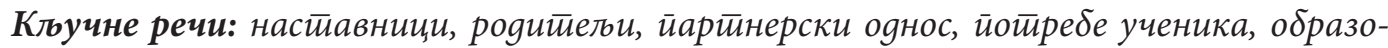
Batbe. 